Chirurgia (2020) 115: $307-313$

No. 3, May - June

Copyright@ Celsius

http://dx.doi.org/10.21614/chirurgia.115.3.307

\title{
What's New in Bipolar TURP for Surgical Management of BPH?
}

\author{
Cosmin Ene, Petrisor Geavlete*, Bogdan Geavlete \\ Department of Urology - "St. John" Clinical Hospital of Emergency, Bucharest, Romania \\ "Carol Davila" University of Medicine and Pharmacy, Bucharest, Romania
}

*Corresponding author:

Professor Petrisor Geavlete

Department of Urology

"Saint John" Emergency Clinical

Hospital, Vitan-Barzesti 13, Sector 4

042122, Bucharest, Romania

E-mail: geavlete@gmail.com

Abbreviations:

TURP - Transurethral resection of the prostate;

LUTS - lower urinary tract symptoms; $\mathrm{BPH}$ - benign prostatic hyperplasia.

Received: 24.02 .2020

Accepted: 14.04 .2020

\section{Rezumat}

\section{Actualităti în TURP bipolar ca tratament chirurgical al hiperplaziei benigne de prostată}

Rezecția transuretrală a prostatei (TURP) este încă considerată standardul de aur pentru tratamentul chirurgical al simptomelor tractului urinar inferior masculin (LUTS) secundar hiperplaziei benigne de prostată (HBP), dar noile metode precum TURP bipolar au devenit o alternativă reală de tratament. Rezecția bipolară prezintă mai multe submetode pentru rezecția eficientă a prostatei: cea mai asemănătoare cu M-TURP este reprezentată de rezecția buclei, apoi vaporizarea transuretrală a prostatei (B-TUVP) care este derivată din TURP bipolar plasmakinetic şi enucleerea, care se numără alături de prostatectomia clasică sau laserul Holmium, de a reprezenta prima alegere a tratamentului chirurgical la bărbații cu o prostată mărită substanțial şi LUTS moderat până la sever. Nu s-a observat nicio diferență statistică între M- TURP şi B- TURP în ceea ce priveşte timpul de intervenție chirurgicală, timpul de cateterizare, scăderea PSA, îmbunătățirea fluxului de vârf (Qmax), apariția retenției urinare şi scorurile IPSS şi calitatea vieții (QoL). Pe de altă parte, B-TURP s-a dovedit a fi superioară M-TURP în raport cu timpul de spitalizare, rata de transfuzie de sânge, sindromul post-TURP, depleția sodiului seric şi apariția mai mică a stenozei uretrale. Atunci când este vorba despre costul procedurii, o meta-analiză la 24 din cele mai relevante publicații din ultimii 20 de ani, a arătat că sistemul TURis demonstrează o eficacitate echivalentă cu MTURP. În concluzie, s-ar putea observa că TURP bipolar reprezintă o alternativă 
viabilă la M-TURP la pacienții cu LUTS moderată până la severă secundară HBP, cu eficacitate similară, dar morbiditate perioperatorie mai mică.

Cuvinte cheie: rezecție bipolară de prostate, hiperplazie benignă de prostată, actualități

\begin{abstract}
Transurethral resection of the prostate (TURP) is still considered the gold standard for male lower urinary tract symptoms (LUTS) secondary to benign prostatic hyperplasia (BPH), but new methods like bipolar TURP became a real treatment alternative. Bipolar resection presents many option for the effective resection of the prostate: the most similar with m-TURP is represented by the loop resection, then transurethral vaporisation of the prostate (B-TUVP) which is derived from plasmakinetic B-TURP and the enucleation, which is among open prostatectomy or holmium laser, the first choice of surgical treatment in men with a substantially enlarged prostate and moderate-to-severe LUTS. There was no statistical difference observed between M-TURP and B-TURP in the parameters of surgery time, catheterization time, PSA drop, peak flow improvement (Qmax), occurrence of urinary retention, and IPSS and quality of life (QoL) scores. On the other hand, B-TURP proved to be superior to M-TURP in relation to hospitalization time, blood transfusion rate, post-TURP syndrome, serum sodium rate and lower occurrence of urethral stenosis. when is about the cost of the procedure, a meta-analysis on 24 from the most relevant publications in the last 20 years, revealed that the TURis system demonstrates equivalent efficacy versus MTURP, In conclusion, it could be observed nowadays that bipolar-TURP represents a viable alternative to M-TURP in patients with moderate to-severe LUTS secondary to BPO, with similar efficacy but lower peri-operative morbidity
\end{abstract}

Key words: bipolar resection of the prostate, benign prostatic hyperplasia, update

\section{Introduction - the definition of bipolar technology and general outcomes}

Transurethral resection of the prostate (TURP) is considered the gold standard for male lower urinary tract symptoms (LUTS) secondary to benign prostatic hyperplasia (BPH), according to EAU Guidelines (1). However, there were permanently under research new operatory methods, using new technologies which to provide better outcomes in term of morbidity and of cost/efficiency rate. Having in mind those desiderates, it appeared new technologies based on laser therapies, including the various types of lasers and alternatives of prostatic tissue ablation (enucleation, vaporization, and resection) and bipolar devices permitting bipolar TURP (B-TURP) or bipolar enucleation. Bipolar techniques were very popular at the beginning because of the short learning curve (2) from TURP to TURisP and because of working in a saline environment, that avoiding post-TUR syndrome (3). During bipolar resection, the energy is confined between the resection loop and the resectoscope tip. Prostatic tissue removal is identical to M-TURP but B-TURP requires less energy/voltage (4). Concerning the efficiency, the last large meta-analysis which included a total of 69 RCTs (8517 enrolled patients), during 12 months evaluating bipolar devices, showed no significant difference between B-TURP and M-TURP on IPSS, QoL score, PVR, and prostate volume. B-TURP procedures, however, seemed to be associated with a higher Qmax. However, the study concluded that supplemental evidence is needed to compare the PVP 180W XPS device 
and modern competitors (including B-TURP and HoLEP). HoLEP became the standard enucleation technique, with satisfactory midterm results and a low complication rate (5). Mamoulakis et al. found no differences in short-term urethral stricture/BNC rates, B-TURP having a more favourable perioperative safety profile (elimination of TURsyndrome; lower clot retention/blood transfusion rates; shorter irrigation, catheterisation, and possibly hospitalisation times) (6). A comparative evaluation between B-TURP and M-TURP on overall sexual function, quantified with IIEF-15, showed similar outcomes at twelve months follow-up (erection, orgasmic function, sexual desire, intercourse satisfaction, overall satisfaction) (7).

\section{Bipolar resection and its subparts}

Bipolar resection presents many option for the effective resection of the prostate: the most similar with $\mathrm{m}$-TURP is represented by the loop resection, then transurethral vaporisation of the prostate (B-TUVP) which is derived from plasmakinetic B-TURP and utilised a high-frequency generator and a bipolar electrode to create a plasma effect able to vaporise prostatic tissue (8). Those devices present an electrode with a specific design, usually looking like a mushroom which has a minimal direct tissue contact, producing a constant plasma field allowing it to vaporise the layer of prostate surface without affecting the capsula (9). The procedure provide a good intraoperative vision, reduced bleeding because of the coagulation provided by the plasma and also an optimal BPH ablation process (10). Also, there are some studies that reported bipolar vaporization as part of a hybrid technique combining it with the simple resection while aiming to optimize tissue removal (Fig. 1) (11). The resection setup involves a standard resectoscope mounting the hemispherical button-shaped electrode and a bipolar generator $(280-320 \mathrm{~W}$ for vaporization and $160 \mathrm{~W}$ for coagulation) (12). The "button" displaying a plasma corona on its' surface produces a gradual, layer-by-layer

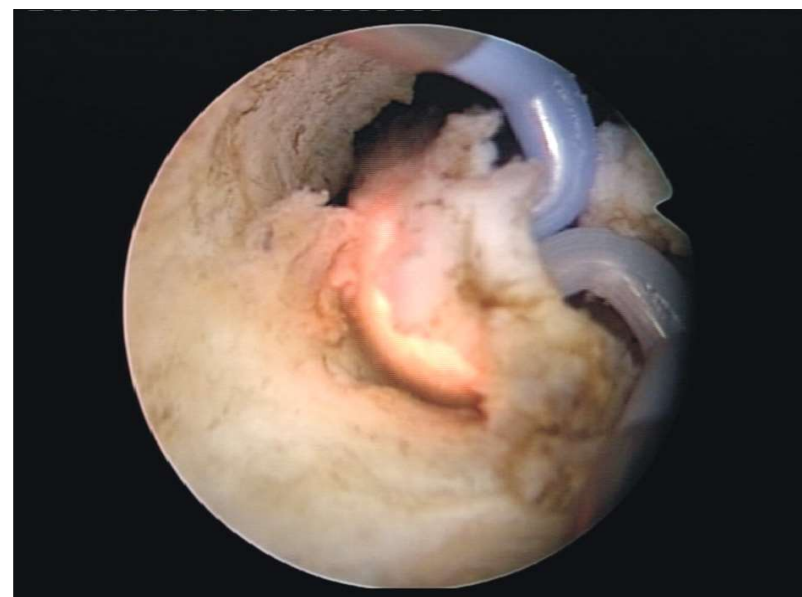

Figure 1. Bipolar plasma resection of the prostate

$\mathrm{BPH}$ bulk removal, beginning from the mucosa surface (Fig. 2) and continuing down to the prostatic capsule until its' muscular fibres become clearly visible (Fig. 3) $(13,14)$. At first, the middle lobe is vaporized starting from the bladder neck, followed by the lateral lobes' ablation (Fig. A) $(13,14)$. The procedure finishes with the anterior lobe vaporization at 12 o'clock and the apical tissue removal around the veru montanum (15). Much to the advantage of the surgeon, the vaporization and haemostasis are practically concomitant, thus creating the conditions for a high-quality endoscopic visibility to be obtained (16). The few remaining bleeding sources are eventually coagulated and a wide prostatic fossa is

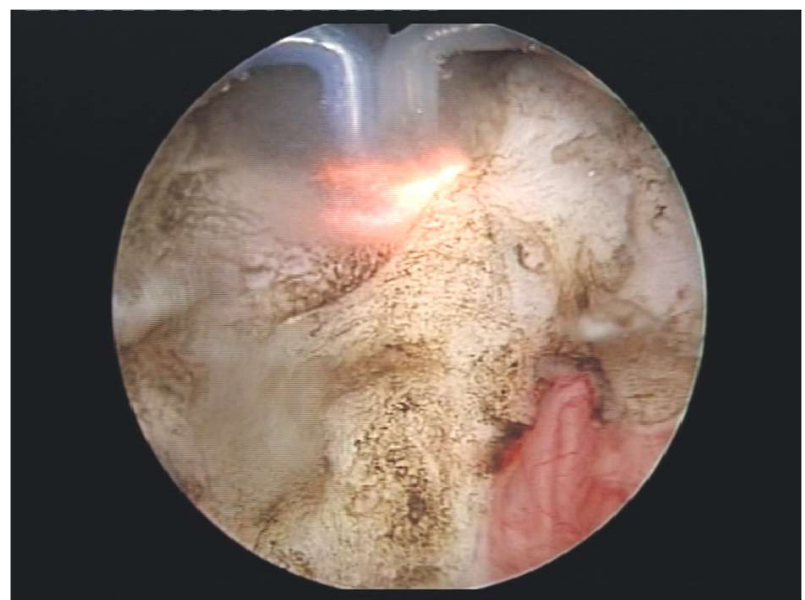

Figure 2. Layer by layer bipolar plasma vaporization of the prostate 


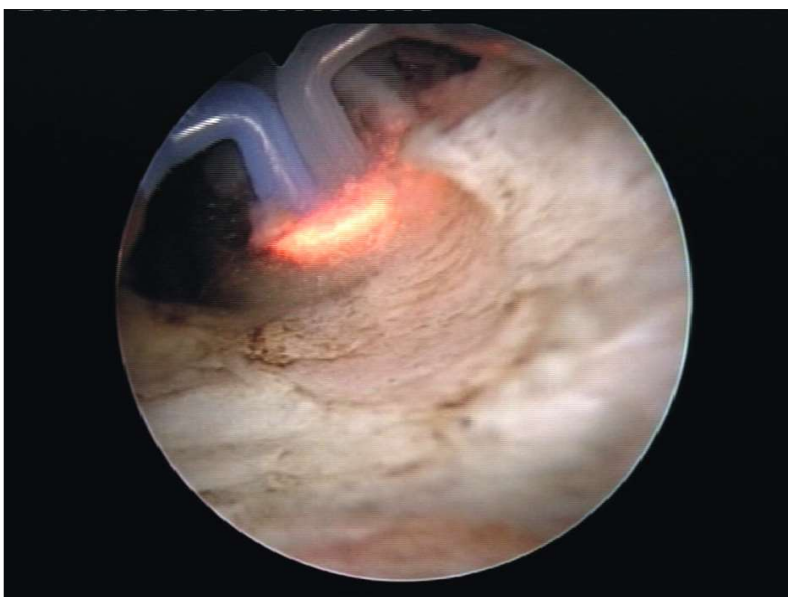

Figure 3. Bipolar plasma vaporization of the prostate to the capsula

obtained, freed from residual irregularities, debris or obstruction (17).

Another type of bipolar intervention on the prostate is represented by the enucleation (Fig. 5), which is among open prostatectomy or holmium laser, the first choice of surgical treatment in men with a substantially enlarged prostate and moderate-to-severe LUTS, according to EAU 2019 Guidelines. Bipolar TUR enucleation of the prostate (B-TUEP) involved enucleation of the prostate using the bipolar TUR system with a bipolar generator (280-320W for vaporization and $160 \mathrm{~W}$ for coagulation). The procedure starts with resection at the 12 o'clock position, then at the 5 and 7 o'clock positions, laterally to the

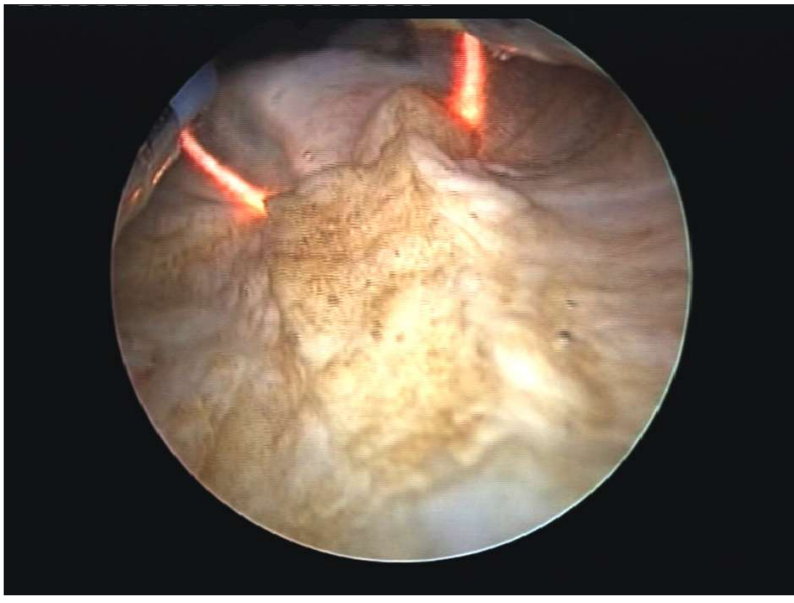

Figure 5. Bipolar enucleation of the prostate

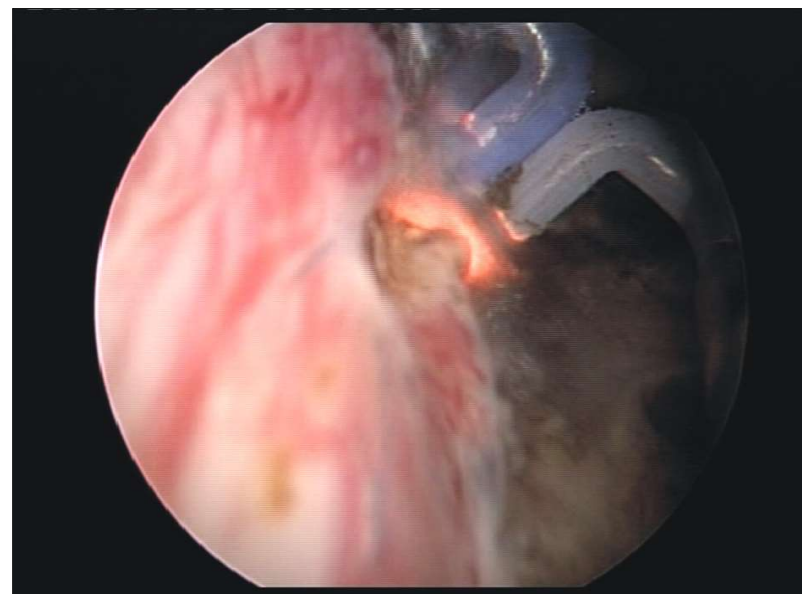

Figure 4. Bipolar plasma vaporization of the prostate from bladder neck to verum montanum

verumontanum, to enucleate the lateral lobes of the prostate. Next, mucosa at the apical adenoma is incised circumferentially. Both lateral lobes and the middle lobe are dissected off the surgical capsule in a retrograde fashion from the apex towards the bladder, with arrest of bleeding. After releasing the lobes into the bladder, tissue morcellation is performed. Afterwards, repeat cystoscopy is performed with the TUR system to ensure that all tissue has been removed and to further create haemostasis if necessary (18).

\section{Bipolar TURP - data from literature}

Concerning the main post-operative parameters (IPSS, Qmax, OoL), there are mediumterm studies but less long-term studies about each of these three methods: bipolar resection, bipolar plasma vaporization and bipolar plasma enucleation. Regarding the bipolar resection, Chen et al. showed similar functional results (on IPSS, Qmax, and QoL score) for B-TURP and HoLEP after 2-yr follow-up in a large RCT including 280 patients, with HoLEP associated with shorter catheterization and hospitalization durations and lower risk of bleeding (19). Also, Olympus TURis and B-TUVP using a button-type vaporesection electrode were compared by Geavlete et al., showing better functional results for the TURis arm, as well as fewer 
postoperative complications $(16,20)$.

In comparison with TURP, in a prospective randomized clinical trial (RCT), including 497 patients with a mean age of 67.4 years and a prostate volume of $54 \mathrm{~cm}^{3}$ were divided into two groups (TURP versus BTURP) and monitored for 36 months. There was no statistical difference in the parameters of surgery time, catheterization time, PSA drop, peak flow improvement (Qmax), occurrence of urinary retention, and IPSS and quality of life (QoL) scores. On the other hand, B-TURP proved to be superior to M-TURP in relation to hospitalization time, blood transfusion rate, post-TURP syndrome, serum sodium rate and lower occurrence of urethral stenosis (22).

The medium and long-term functional outcomes were also described as satisfactory by the available studies analyzing the plasma vaporization patients' series (21). More precisely, substantial progresses were encountered concerning the maximum flow rate (Qmax) (16.3-25.6 for BPVP versus 12.5-23.5 for TURP), International Prostate Symptom Score (IPSS) (4.2-7.7 versus 6.9-9.3, respectively), Quality of Life score (QoL) (1-1.7 for BPVP versus 1.5-2.6 for TURP) and postvoiding residual urinary volume (PVR) (11-64 $\mathrm{mL}$ versus $69 \mathrm{~mL})(13,14,22)$. Consequently, it was concluded that the plasma-button treatment benefits in terms of symptom scores and urodynamic features are significant and persistent during the medium-tolong term follow-up period (13).

Bipolar enucleation, among HoLEP tends to be a very good option with promising outcomes, that being observed by Giulianelli and Zhu et al. which showed a significant improvement in terms of QoL after plasmakinetic enucleation (PKEP) and resection in comparison with the initial status $(23,24)$. Also, when comparing the QoL secondary to transurethral enucleation and resection of the prostate (TUERP) and bipolar TURP in large BPO cases, there were observed similar outcomes (25). Meanwhile, as far as the short and medium-term findings were concerned, the literature data emphasized that PKEP obtained similar advantages by comparison to bipolar TURP in large prostates, while better QoL figures were outlined during the longterm surveillance (26).

ThuLEP and bipolar enucleation were compared in a twelve months follow-up RCT. The outcomes showed same efficacy. Meanwhile, the decrease in haemoglobin level and catheter time were reduced for ThuLEP (27). An RCT with five years follow-up compared ThuLEP with bipolar TURP and found differences between the two procedures in terms of Qmax, IPSS, PVR, and QoL (28).

Meanwhile, there are combined methods, that proved better outcomes than the single method, like PKRP combined with thulium laser which was superior than PKRP only, having better surgical duration, less bleeding, higher efficiency and much quicker recovery, in a small study on 61 patients with large prostate (29).

Another wery studied intervention method in benign prostatic hyperplasia, constantly compared with TURP (gold standard) is PAE (prostatic artery embolisation). The UKROPE trial (21) reports on safety and efficacy outcomes of PAE versus TURP in 315 men and concludes that PAE is a procedure with minimal complications that offers a valuable option for patients who are positioned between medication and surgery on their care pathway (30) while the conclusion of the study is that PAE might be a valuable alternative for the treatment of BPH-LUTS in a selected group of patients in whom the indication for surgery is primarily based on their symptoms. (31). Overall it can be observed a significant improvement of the post-operative parameters (IPSS, QoL, Qmax, PVR) in patients undergoing bipolar interventions (TURis, BPVP, BPEP), in comparison with TURP, even if the last one, still remain the gold standard (Table 1).

Last but not least, when is about the cost of the procedure, a meta-analysis on 24 from the most relevant publications in the last 20 years, revealed that the TURis system demonstrates equivalent efficacy versus MTURP, the current standard of care and is associated with statistically significant improvements in perioperative safety and duration of hospital 
Table 1. The evolution of post-operative parameters BPVP, BPEP, TURis versus TURP $(13,14,20,21,26,33)$.

\begin{tabular}{lcccccccc}
\hline & Qmax preop & Qmax postop & IPSS preop & IPSS postop & QoL preop & QoL postop & PVR preop & PVR postop \\
\hline BPVP & $4.4-10.1$ & $16.3-25.6$ & $16-24.6$ & $4.2-7.7$ & $4-5.1$ & $1-1.7$ & $87-1000 \mathrm{~mL}$ & $11-64 \mathrm{~mL}$ \\
\hline BPEP & $4.7-9.3$ & $25-25.6$ & $24.5-24.7$ & $4.2-8.3$ & $4.1-42$. & $0.9-1$ & $134.1-210 \mathrm{~mL}$ & $4-19.7 \mathrm{~mL}$ \\
\hline TURis & $4.4-6.4$ & $22.1-24.9$ & $25-25.2$ & $4.4-4.9$ & $4-4.4$ & $0.9-1$ & $151.5-290 \mathrm{~mL}$ & $15-27.6 \mathrm{~mL}$ \\
\hline TURP & $5.3-10.1$ & $12.5-23.5$ & $16-27.3$ & $6.9-9.3$ & $4-5.1$ & $1.5-2.6$ & $87-1000 \mathrm{~mL}$ & $69 \mathrm{~mL}$ \\
\hline
\end{tabular}

stay while the clinical benefits of TURis have the potential to translate into cost savings because TURis is not associated with a steep learning curve for surgeons (32).

\section{Conclusions}

Overall, according to EAU 2020 Guidelines and based on long term studies, it could be observed nowadays that bipolar-TURP represents a viable option to M-TURP in patients with moderate to-severe LUTS secondary to BPO, having similar efficacy but lower peri-operative morbidity.

\section{Conflict of Interest}

The authors mention that there is not any conflict of interest.

\section{References}

1. Sønksen J, Barber NJ, Speakman MJ, Berges R, Wetterauer U, Greene D, et al. Prospective, randomized, multinational study of prostatic urethral lift versus transurethral resection of the prostate: 12-month results from the BPH6 study. Eur Urol. 2015;68(4):643-52.

2. Nunes RLV, Antunes AA, Constantin DS. Contemporary surgical treatment of benign prostatic hyperplasia. Rev Assoc Med Bras (1992). 2017;63(8):711-716

3. Chen SS, Chiu AW, Lin AT, Chen KK, Chang LS. Clinical outcome at 3 months after transurethral vaporization of prostate for benign prostatic hyperplasia. Urology. 1997;50(2):235-8.

4. Issa MM. Technological advances in transurethral resection of the prostate: bipolar versus monopolar TURP. J Endourol. 2008 22(8):1587-95.

5. Cornu JN, Ahyai S, Bachmann A, de la Rosette J, Gilling P, Gratzke $C$, et al. A Systematic Review and Meta-analysis of Functional Outcomes and Complications Following Transurethral Procedures for Lower Urinary Tract Symptoms Resulting from Benign Prostatic Obstruction: An Update. Eur Urol. 2015;67(6):1066-1096.

6. Mamoulakis C, Ubbink DT, de la Rosette JJ. Bipolar versus monopolar transurethral resection of the prostate: a systematic review and meta-analysis of randomized controlled trials. Eur Urol. 2009;56(5):798-809.

7. Mamoulakis, C, Skolarikos A, Schulze M, Scoffone CM, Rassweiler JJ, Alivizatos G, et al. Bipolar vs monopolar transurethral resection of the prostate: evaluation of the impact on overall sexual function in an international randomized controlled trial setting. BJU Int. 2013;112(1):109-20.

8. Botto $\mathrm{H}$, Lebret T, Barré P, Orsoni JL, Hervé JM, Lugagne PM. Electrovaporization of the prostate with the Gyrus device. J Endourol. 2001;15(3):313-6.

9. Bucuras V, Bardan R. Bipolar vaporization of the prostate: Is it ready for the primetime? Ther Adv Urol. 2011;3(6):257-61.

10. Kaya C, Ilktac A, Gokmen E, Ozturk M, Karaman IM. The long-term results of transurethral vaporization of the prostate using plasmakinetic energy. BJU Int. 2007;99(4):845-8.

11. Jepsen JV, Bruskewitz RC. Recent developments in the surgical management of benign prostatic hyperplasia. Urology. 1998; 51(4A Suppl):23-31.

12. Cabelin MA, Te AE, Kaplan SA. Transurethral vaporization of the prostate: Current techniques. Current Urology Reports. 2000; 1(2): 116-23.

13. Zhang SY, Hu H, Zhang XP, Wang D, Xu KX, Na YQ, et al. Efficacy and safety of bipolar plasma vaporization of the prostate with "button-type" electrode compared with transurethral resection of prostate for benign prostatic hyperplasia. Chin Med J (Engl). 2012;125(21):3811-4.

14. Kranzbühler B, Wettstein MS, Fankhauser CD, Grossmann NC, Gross 0 , Poyet $C$, et al. Pure bipolar plasma vaporization of the prostate: the Zürich experience. J Endourol. 2013; 27(10):1261-6.

15. Tefekli A, Muslumanoglu AY, Baykal M, Binbay M, Tas A, Altunrende F. A hybrid technique using bipolar energy in transurethral prostate surgery: a prospective, randomized comparison. J Urol. 2005; 174(4 Pt 1):1339-43.

16. Geavlete B, Georgescu D, Multescu R, Stanescu F, Jecu M, Geavlete P. Bipolar plasma vaporization vs monopolar and bipolar TURP-A prospective, randomized, long-term comparison. Urology. 2011; 78(4):930-5.

17. Reich O, Schlenker B, Gratzke C, Tilki D, Riecken M, Stief C, Seitz $M$, Bachmann A.. Plasma vaporisation of the prostate: initial clinical results. Eur Urol. 2010;57(4):693-7.

18. Boeri L, Capogrosso P, Ventimiglia E, Fontana M, Sampogna G, Zanetti SP, et al.Clinical Comparison of Holmium Laser Enucleation of the Prostate and Bipolar Transurethral Enucleation of the Prostate in Patients Under Either Anticoagulation or Antiplatelet Therapy. Eur Urol Focus. 2019:S2405-4569(19)30077-X.

19. Chen YB, Chen $Q$, Wang Z, Peng YB, Ma LM, Zheng DC, et al. A prospective, randomized clinical trial comparing plasmakinetic resection of the prostate with holmium laser enucleation of the prostate based on a 2-year followup. J Urol 2013;189(1):217-22.

20. Geavlete B, Bulai C, Ene C, Checherita I, Geavlete P. Bipolar Vaporization, Resection, and Enucleation Versus Open Prostatectomy: Optimal Treatment Alternatives in Large Prostate Cases? J Endourol. 2015;29(3):323-31.

21. Al-Rawashdah SF, Pastore AL, Salhi YA, Fuschi A, Petrozza V, Maurizi A, Illiano E, Costantini E, Palleschi G, Carbone A. Prospective randomized study comparing monopolar with bipolar transurethral resection of prostate in benign prostatic obstruction: 36-month outcomes. World J Urol. 2017;35(10):1595-1601.

22. Hon NH, Brathwaite D, Hussain Z, Ghiblawi S, Brace H, Hayne D, Coppinger SW.A prospective, randomized trial comparing 
conventional transurethral prostate resection with PlasmaKinetic vaporization of the prostate: physiological changes, early complications and long-term follow-up. J Urol. 2006;176(1):205-9.

23. Giulianelli R, Gentile BC, Mirabile G, Albanesi L, Tariciotti P, Rizzo $G$, et al. Bipolar Plasma Enucleation of the Prostate (B-TUEP) in Benign Prostate Hypertrophy Treatment. 3-Year Results".Urology. 2017 May 30. pii: S0090-4295(17)30514-9.

24. Zhu G, Xie C, Wang X, Tang X. Bipolar plasmakinetic transurethral resection of prostate in 132 consecutive patients with large gland: three-year follow-up results. Urology. 2012;79(2):397-402.

25. Wei Y, Xu N, Chen SH, Li XD, Zheng QS, Lin YZ, Xue XY. Bipolar transurethral enucleation and resection of the prostate versus bipolar resection of the prostate for prostates larger than $60 \mathrm{gr}$ : A retrospective study at a single academic tertiary care center. IntBraz J Urol. 2016;42(4):747-56

26. Zhu L, Chen S, Yang S, Wu M, Ge R, Wu W, et al. Electrosurgical enucleation versus bipolar transurethral resection for prostates larger than $70 \mathrm{ml}$ : a prospective, randomized trial with 5-year follow-up. J Urol. 2013;189(4):1427-31.

27. Feng L, Zhang D, Tian Y, Song J. Thulium Laser Enucleation Versus Plasmakinetic Enucleation of the Prostate: A Randomized Trial of a Single Center. J Endourol. 2016;30(6):665-70.

28. Yang, Z, Liu T, Wang X. Comparison of thulium laser enucleation and plasmakinetic resection of the prostate in a randomized prospective trial with 5-year follow-up. Lasers Med Sci.
2016;31(9):1797-1802.

29. Xie T, Lai $P$, Luo M, Xu Y. The Effectiveness and Safety of Transurethral (Bipolar) Plasmakinetic Resection of Prostate Combined with Thulium Laser for Large Benign Prostatic Hyperplasia (>80ml). Urol J. 2016;13(6):2889-2892.

30. Ray AF, Powell J, Speakman MJ, et al. Efficacy and safety of prostate artery embolization for benign prostatic hyperplasia: an observational study and propensity-matched comparison with transurethral resection of the prostate (the UK-ROPE study). BJU Int 2018;122:270-82.

31. Zumstein V, Betschart P, Vetterlein MW, Kluth LA, Hechelhammer L, Mordasini L, Engeler DS, Kessler TM, Schmid HP, Abt D. Prostatic Artery Embolization versus Standard Surgical Treatment for Lower Urinary Tract Symptoms Secondary to Benign Prostatic Hyperplasia: A Systematic Review and Meta-analysis. Eur Urol Focus. 2018. pii: S2405-4569(18)30277-3

32. Treharne C, Crowe L, Booth D, Ihara Z. Economic Value of the Transurethral Resection in Saline System for Treatment of Benign Prostatic Hyperplasia in England and Wales: Systematic Review, Meta-analysis, and Cost-Consequence Model. Eur Urol Focus. 2018;4(2):270-279

33. Mallikarjuna C, Nayak P, Ghouse SM, Reddy PC, Ragoori D, Bendigeri MT, Reddy S. Transurethral enucleation with bipolar energy for surgical management of benign prostatic hyperplasia: Our initial experience. Indian J Urol. 2018;34(3): 219-222. 